УДК 343

DOI: $10.14451 / 2.149 .10$

\title{
КВАЛИФИКАЦИЯ ПРЕСТУПЛЕНИЙ, СВЯЗАННЫХ С НЕПРАВОМЕРНЫМИ ДЕЙСТВИЯМИ ПРИ БАНКРОТСТВЕ
}

\author{
() 2020 Ибрагимов Юсуп Муслимович \\ ассистент кафедры теории и технологии социальной работы \\ Чеченский государственный университет, Чеченская Республика, Грозный \\ E-mail: yusuf_ibr@mail.ru \\ (c) 2020 Ибрагимова Киса Магомед-Салиховна \\ ассистент кафедры «Информационное право и юриспруденция» \\ Грозненский государственный нефтяной технический университет, \\ Чеченская Республика, Грозный
}

В настоящей статье рассматриваются вопросы квалификации преступлений связных с неправомерными действиями при банкротстве. Приводится общая статистика преступлений в сфере банкротства. Проводится детальный анализ каждой части ст. 195 УК РФ. Выявляются проблемы и предлагаются пути их решения.

Ключевые слова: банкротство, уголовное право, ответственность, неправомерные действия, должник.

В 2016 году подверглись процедуре банкротства порядка 121 тысячи организаций, причем многими допускаются существенные нарушения закона. Преступления, совершаемые в сфере банкротства, в условиях современного развития государства набирают свою популярность. В нашей стране, согласно статистике, количество поданных заявлений и количество возбуждённых уголовных дел растет.

Современный Уголовный кодекс РФ предполагает три вида неправомерных банкротств:

1. Неправомерные действия при банкротстве (ст. 195 УК РФ). В юридической литературе данное преступление называется «злостное банкротство» [10, С. 52].

2. Преднамеренное банкротство (ст. 196 УК РФ). В юридической литературе такое преступление именуется как, «умышленное банкротство» [11, С. 14].

3. Фиктивное банкротство (ст. 197 УК РФ).

Общественная опасность рассматриваемых преступлений заключается в подрыве экономических отношений в стране [12, С. 14].

Наиболее часто встречающимся в практике преступлением, считается преступление, предусмотренное ст. 195 УК РФ, которому и посвящена данная статья. Если обратимся к данной статье, то не увидим четкое определение что считать данным преступлением. В статье указан лишь перечень действий, которые необходимо считать преступными. Но в юридической лите- ратуре многие авторы пытаются дать определение данному преступлению. Так, например, А.Г.Кудрявцев под неправомерными действиями понимает «воспрепятствование нормальному ходу конкурсного производства» [13, С. 9]. Б.И. Колб неправомерными действиями считает уменьшение конкурсной массы [11, С. 15].

Таким образом, закономерным является вопрос, касающийся квалификации данного деяния. Достаточно ли одного признака объективной стороны, указанного в ч. 1 ст. 195 УК РФ, либо необходима их совокупность для признания деяния преступным? По нашему мнению, при условии формально-логического толкования диспозиции статьи можно сделать вывод, что перечисление действий, предметом которых являются бухгалтерские и иные учетные документы, имеет смысл лишь в случае их альтернативности. Т.е. необходимо признать самостоятельность каждого признака объективной стороны. Однако из данного правила есть и исключения, так из смысла анализируемой нормы не вытекает возможность выбора при квалификации одного из действий, когда речь идет о сокрытии имущественных обязательств и сведений об имуществе, а также по отношению к ним действий применительно к бухгалтерским и иным учетным документам, отражающим экономическую деятельность.

Обязательным признаком объективной стороны банкротства является обстановка - т.е. на- 
личие признаков банкротства. Такая обстановка имеет место, когда арбитражный суд возбудил производство по делу в соответствии с ФЗ от 26.10.2002 № 127-ФЗ «О несостоятельности (банкротстве)», либо имеются признаки банкротства, указанные в п. 2 ст. 3 ФЗ «О несостоятельности (банкротстве)». Так, отсутствие возбужденного производства о банкротстве не исключает возможности привлечения лица к ответственности по ст. 195 УК РФ.

Вышеизложенное подтверждается и судебной практикой. Так руководитель товарищества К. зная, что его организация находится в предбанкротном состоянии, т.к. имеется задолженность по налоговым платежам в течении 3-х месяцев, вывел из организации имущество и материальные ценности, чем причинил крупный ущерб. В данном случае, арбитражный суд еще не возбуждал дело о несостоятельности (банкротстве), но имелись признаки банкротства. Таким образом, действия руководителя были квалифицированы по ч. 1 ст. 195 УК РФ [6].

Ч. 2 ст. 195 предусматривает самостоятельный вид неправомерных действий - неправомерное удовлетворение имущественных требований отдельных кредиторов за счет имущества должника - юридического лица руководителем юридического лица либо гражданином, в том числе ИП, заведомо в ущерб другим кредиторам, если это деяние совершено при наличии признаков банкротства и причинило крупный ущерб.

Данное деяние посягает на установленные законом требования по удовлетворению интересов кредиторов, при наличии у должника признаков банкротства.

Объективную сторону образуют:

- Действие. Неправомерное удовлетворение имущественных требований отдельных кредиторов за счет имущества должника, заведомо в ущерб другим кредиторам. Отсюда вопрос: в чем заключается эта неправомерность? По нашему мнению, неправомерность заключается в нарушении принципов очередности и пропорциональности при удовлетворении интересов кредиторов. Данные принципы установлены ФЗ «О несостоятельности (банкротстве)».

- Последствие. Крупный ущерб. В настоящее время в данной статье крупный ущерб это оценочное понятие. Судья самостоятельно устанавливает является ли определенная сумма крупным ущербом для организации, ИП или гражданина. Такая ситуация полностью отвечает принципу индивидуализации уголовной ответственности т.к. финансовое положение у организации, ИП и граждан совершенно различное. Однако в целях избегания споров и разногласий при определении признаков объективной стороны, мы считаем необходимо, сумму ущерба закрепить на законодательном уровне.

- Причинная связь между действием и последствием.

Субъект преступления - специальный, т.е. руководитель или учредитель какой-либо организации, либо ИП. Субъективная сторона заключается в прямом умысле. Т.е. виновный осознает, что удовлетворяет требования кредитора в нарушении принципов очередности и пропорциональности; предвидит, что наступят последствия для других кредиторов в крупном размере; желает, чтобы последствия наступили.

Ч. 3 ст. 195 УК РФ устанавливает ответственность за незаконное воспрепятствование деятельности арбитражного управляющего, либо временной администрации или иной финансовой организации, при условии, что эти деяния причинили крупный ущерб.

Обязанность по предоставлению сведений о финансовой и хозяйственной деятельности организации возложена на лиц в соответствии с п. 3.2 ст. 64 и п. 2 ст. 129 ФЗ «О несостоятельности (банкротстве)». Общественная опасность данного деяния заключается в ограничении возможностей арбитражного управляющего. Тем самым он не может выявить причин банкротства, не может проанализировать финансовую деятельность организации, не надлежащим образом формирует конкурсную массу и т.д.

Приведу пример из судебной практики. В отношении ООО «Амер» Арбитражным судом было возбуждено дело о несостоятельности (банкротстве). Руководитель ООО «Амер» Е. по запросу временного управляющего отказался передавать последнему документы, затрагивающие финансовую деятельность организации, бухгалтерскую документацию и печати. Таким образом, Е. осужден по ч. 3 ст. 195 УК РФ незаконно воспрепятствовал деятельности временной администрации [8].

При анализе статьи 195 УК РФ заметим, что в ней отсутствуют квалифицирующие признаки. Однако, по нашему мнению, глупо отрицать повышенную общественную опасность при совершении преступления группой лиц. Поэтому мы предлагаем дополнить статью квалифицирую- 
щими признаками.

Интересным по данному факту является приговор, в котором преступление совершено группой лиц по предварительному сговору, но это не нашло отражения в приговоре. Так, А., Е., Р., К., и П., создали в 2013 году ОАО уставной капитал, которого составлял 10 млн. руб. При проведении процедуры банкротства акционеры скрывали документацию о дочерних фирмах OAO «Петр», ООО «Березка», ОАО «Спалк», а также печати и бухгалтерскую документацию, действуя в сговоре. Тем самым их действия были квалифицированы по ч. 3 ст. 195 УК РФ [9].

Таким образом, на основе всего вышеизложенного, для решения рассматриваемых проблем считаем, что необходимо внести изменения в ст. 195 УК РФ. Во-первых, законодателю необходимо четко указать, что в чем суть неправомерных действий, а уже потом перечислять эти действия. Суть их в том, что они посягают на нормальный ход конкурсного производства. Во-вторых, необходимо установить примечание к ст. 195 УК РФ, в котором указать какой ущерб является крупным. Так, мы предлагаем изложить примечание в следующем виде: «крупным ущербом в настоящей статье признается ущерб: для юридических лиц -1 млн. руб.; для ИП 500 тыс. руб.». А, в-третьих, необходимо дополнить статью квалифицирующими признаками. Дополнить статью ч. 4 и 5 в следующем виде: «4. Деяния, предусмотренные частью первой, второй или третьей настоящей статьи, совершенные: а) группой лиц по предварительному сговору,- наказываются ... 5. Деяния, предусмотренные частью первой, второй или третьей настоящей статьи, совершенные: а) организованной группой,- наказываются ...».

\section{Библиографический список}

1. Уголовный кодекс Российской Федерации.- М.: Проспект: КноРус, 2020. - 224 с.

2. Гражданский кодекс Российской Федерации. Часть первая, вторая, третья и четвертая.- М.: Проспект: КноРус, 2020.- 544 с.

3. Гражданский процессуальный кодекс Российской Федерации.- М.: Проспект: КноРус, 2020.-176 с.

4. Федеральный закон от 26.10.2002 № 127-ФЗ «О несостоятельности (банкротстве)»._- М.: Проспект: КноРус, 2020.- 54 c.

5. Решение Пермского городского суда Пермского края от 25 сентября 2014 г. // СПС «Консультант Плюс» [Электронный ресурс].- Режим доступа: http://www.consultant.ru.

6. Решение Макарьевского районного суда Костромской области от 29 июля 2010 г. // СПС «Консультант Плюс» [Электронный ресурс].- Режим доступа: http://www.consultant.ru.

7. Решение Карамаскалинского районного суда Республики Башкортостан от 28 февраля 2011 г. по делу № 1-27/2011 // СПС «Консультант Плюс» [Электронный ресурс]. - Режим доступа: http://www.consultant.ru.

8. Решение Вологодского городского суда Вологодской области от 13 декабря 2016 года // СПС «Консультант Плюс» [Электронный ресурс].- Режим доступа: http://www.consultant.ru.

9. Решение Тимирязевского районного суда г. Москвы от 25 ноября 2016 г. // СПС «Консультант Плюс» [Электронный ресурс].- Режим доступа:

10. Клепицкий И. А. Банкротство как преступление в современном уголовном праве/И. А. Клепицкий // Государство и право, 2013. № 11.

11. Колб Б. И. Субъекты криминальных банкротств/Б. И. Колб//Законность, 2014. № 3.

12. Колб Б. И. Объективная сторона криминальных банкротств /Б. Ю. Колб //Законность, 2014. № 1.

13. Кудрявцев А.Г.Актуальные проблему уголовной ответственности за преступления, связанные с банкротством, на современном этапе: Дис... канд. юрид. наук/А. Г. Кудрявцев. Воронеж, 2003. 